\title{
THE REPUBLIC OF INDONESIA GOVERNMENT PUBLIC RELATIONS COMMUNICATION STRATEGY IN THE ERA OF THE INDUSTRIAL REVOLUTION 4.0
}

\author{
Amri Dunan* \& Bambang Mudjiyanto \\ ( ${ }^{*}$ First author) \\ Human Research Resources \& Development Agency, The Ministry of \\ Communication \& Informatics \\ Jakarta Pusat 10110 Indonesia. \\ (amri007@kominfo.go.id; bamb037@kominfo.go.id) \\ Doi: https://doi.org/10.22452/jati.vol25no1.4
}

\begin{abstract}
In the current 4.0 Industrial Revolution era, Government Public Relations-GPR is required to be able to adapt to the development of advanced technologies such as Artificial Intelligent-AI, Robotic, Drone and Big Data Analytics. It is a challenge for the GPR of the Republic of Indonesia in improving public information services to be quicker and precise through online media. This article aims to identify the GPR communication strategy of the Ministry of Communication and Information Technology in the era of the Industrial Revolution 4.0. This study uses a qualitative approach with Focus Group Discussions (FGD) as the data collection method. The categorisation of the FGD data results was carried out to describe the existing conditions and expected conditions of the GPR in Industrial Revolution era 4.0. The matrix frame is carried out to identify the GPR communication strategy. The result of this study indicates that the Ministry of Communication and Informatics of the Republic of Indonesia needs to be equipped with $\mathrm{AI}$ and Big Data Analytics in implementing communication systems automatically. It was found that there are two communication strategies which can be used by the GPR of Ministry of Communication and Informatics in the Industrial Revolution 4.0 era, namely content automation and digital story telling. In addition, it also needs to be supported by experts in the fields of Public Relations, Data Analyst and Data Learning. The ability of public relations equipped with skills in advanced technology such as AI can support the implementation of communication strategies.
\end{abstract}

Keywords: GPR, 4.0, artificial intelligent, big data analytics, communication strategy 


\section{Introduction}

At present, we are in the Industrial Revolution 4.0 era. Advanced technology exists to simplify the product production process, and the presence of robotics technology is predicted to replace the role of humans. Artificial intelligent technology (AI) has been used in various industries, such as automotive, electronics, medicine, exploration, and transportation, which have begun to feel the disruption effect. In the future, the role of humans will be increasingly reduced and replaced with AI technology because the communication patterns that occur is not only between humans but also between humans and machines, even the interaction between the machines. The 4.0 industry complex presents several challenges and requires several industries to carry out the transformation, one of which is the public relations-PR industry, especially in this case, the government's public relations. The existence of advanced technologies such as AI, Robotic, Drone and Big Data Analytics is a challenge for the GPR of the Ministry of Communication and Informatics Republic of Indonesia in improving public information services to be quicker and precise through online media. The results of the Survey of the Indonesia Internet Service Providers Association - APJII show that internet users penetrated as many as 171 million of the total Indonesian population of 264 million people (APJII, 2019). Thus approximately 64.8 percent of Indonesia's population have the opportunity to access public policy information through online media. This is in line with the Presidential Instruction No. 9 of 2015 concerning Management of Public Communications which aims to absorb public aspirations and accelerate information concerning government policies and programmes. Various methods of disseminating public policy information are carried out by the Ministry of Communication and Informatics, both offline and online. Specifically for online, the strengthening of publications through social media is carried out by the Ministry of Communication and Informatics by utilising cyber army in ministries or institutions and endorsers.

\section{Problem Statement}

Social media has become one of the most effective GPR tools in building public trust for the government. However, social media is also the most widely used negative content distribution tool. Based on the results of the survey of Telecommunications Society where 1,116 respondents have taken part in, social media is the highest channel of hoax distribution in the form of writing, images, and videos (Mastel, 2017). In connection with these problems, the use of advanced technology, especially AI to overcome the massive and fast spreading 
content is urgent for GPR. Therefore, this article seeks to answer the research question: What is the communication strategy of the Ministry of Communication and Informatics GPR in the era of the Industrial Revolution 4.0? Based on the research question, the objective of this research is to identify the GPR communication strategy of the Ministry of Communication and Informatics in the era of the Industrial Revolution 4.0.

\section{Literature Review}

The Industrial Revolution 4.0 is often cited on various occasions attended by Heads of State and Heads of Government. The era of the fourth Industrial Revolution is a phenomenon marked by the presence of technological advances that can be connected in everyday life. The phrase Industrial Revolution 4.0 has been mentioned since 2016 by an economist from Germany, Professor Klaus Schwab in World Economic Forum in Davos-Klosters, Switzerland (Savitri, 2019). Before entering the current era, the Industrial Revolution had been discovered since the 1700 s until the early 1800 s. As the name suggests, the industry evolved from the first stage until now, which has entered the fourth stage. The number of technological breakthroughs in a number of fields and the number of new ways of adapting the capabilities of existing technology are strong reasons the 4.0 industrial revolution cannot be compared to the digital revolution. According to (Savitri, 2019), the fourth era of the Industrial Revolution was marked by a blend of technology that blurred the boundaries between physical, digital and biological fields, or collectively referred to as the cyber-physical system (CPS). The world has entered the so-called fourthgeneration internet. The Internet of Things is part of the 4.0 Industrial Revolution era. Another close connection is that human life today will change and make use of internet devices as well as robotics and artificial intelligence (Skinner, 2018).

The Industrial Revolution 4.0 is also related to the great progress in our lives because of automation. The concept of automation carried out by machine is said not to require human labour in its application. This causes efficiency in the industry as well as time, labour and cost efficiency. One of the impacts or risks that occur from automation which is of the most cause of concern is the absorption of its workforce. Even so, this was denied by the Indonesian government, which stated that there were huge opportunities for new jobs in Indonesia that could absorb the workforce in the industrial sector and even the industrial support services sector. The Minister of Industry for the 2014-2019 period, Airlangga Hartanto said that this era would also provide new employment opportunities in Indonesia for up to 18 million people, with 4.5 
million new workers absorbed by the industrial sector and another 12.5 million by the industrial support services sector (Ministry of Industry, 2018).

The Indonesian government indeed looks very serious facing the Industrial Revolution 4.0. One proof is the agenda of Making Indonesia 4.0 in 2018, which was attended by President Joko Widodo. Making Indonesia 4.0 is said to provide clear direction for the future movement of the national industry, including a focus on developing five manufacturing sectors that will be piloted and will carry out 10 national initiatives to strengthen Indonesia's industrial structure (Deny, 2018). This road map is also expected to grow real GDP by $1-2 \%$ per year.

In fact, in 2019, the Government of Indonesia also launched the Indonesia Industry 4.0 Readiness Index (INDI 4.0) at the Indonesia Industrial Summit (IIS) 2019 last. INDI 4.0 is an indicator of the level of industry readiness in Indonesia in applying 4.0 technology industry era. The Minister of Industry, Airlangga Hartarto also mentioned that INDI 4.0 was part of Making Indonesia 4.0, a road map to achieve Indonesia's goal of becoming the world's top 10 economies in 2030 (Sukmana, 2019).

One of the scenarios which can be accomplished by the government in facing the fourth Industrial Revolution is to open business opportunities since the government will also not be able to control this phenomenon (Lye, 2017). However, what needs to be done is to adjust the existing policies such as the Making Indonesia 4.0 roadmap.

The anxiety that workers will be overwhelmed by technology in the era of Industrial Revolution 4.0 demanded the education and training of human resources to be able to keep up with the changes. The impact of the 4.0 Industrial Revolution is indeed for education and training. Due to the reason, these special needs and skills require all human resources to be able to adapt to their changing roles and responsibilities in their respective industries. Various types of work increasingly require more complex expertise, especially since at present, they have to adapt to the existing technology. Although many say technology can replace the role of humans, there is creativity and critical power possessed by human intelligence which cannot be replaced even by robots (Agolla, 2018). Furthermore, education and competence in the context of the 4.0 Industrial Revolution began with technology literacy, information literacy, media creativity, social responsibility. With the development of this technology, it also makes the dissemination of information rapidly increase to ensure human resources have new skills with critical access and process content to assure the best social communication and interaction. As Charles Darwin said 160 years ago: "it is not the strongest of the species that survives, nor the most intelligent; it 
is the one most adaptable to change" (Laksamana, 2018). So, it can be said that humans are the most adaptable creatures.

Artificial Intelligence is a field of computer science emphasising on the creation of intelligent machines signifying it works and reacts like humans (Savitri, 2019). This AI can be anything from Google Assistant to self-driving, bot conversation platforms, etc. Even with this technology, computers can be used to complete certain tasks from large amounts of data to recognising patterns in data.

In addition to using data to analyse deeper, AI also tends to adapt through progressive learning algorithms and will add intelligence to existing products. AI is usually also used to cover speech recognition, deep learning, planning to problem-solving. Although AI can be said to be super smart, it cannot show emotions existing in humans such as love or hate.

Meanwhile, big data or metadata is a term used to describe a very large volume of data. It cannot be said that the data is well structured, but big data is an initial process of 'collecting data' before the data is finally analysed for a purpose. Big data has actually been known for a long time but this term has only just been discovered. Users are those who really need a large amount of data processed. So, big data is not just a collection of data in a very large form. However, the processing, analysis and results found are also the most important in this big data. This big data can also be linked to data science of how existing data is used in a study. This big data will facilitate the process of collecting data for the needs of studies as in this data science.

A number of researchers have conducted several studies linking the role of advanced technology such as AI in Public Relations-PR. Some support the existence of $\mathrm{AI}$ in public relations, but some tend to be otherwise. PR depends on how to build relationships between brands and stakeholders through "personable interaction". This did not exist when AI sent the message (Scott, 2018). Scott (2018) argues the result is a low public perception of its transparency and authenticity. If public relations is the discipline which looks after reputation and reputation is associated with trust (Dolphin, 2004), it can be said that: "Humans build trust with humans - not bots" (Ristic, 2017).

A learning algorithm monitored by solid training data may be able to manage some promotions through social media, thereby allowing some social media engagement to be increased (Lynch, 2018). Lynch (2018) also suggested that AI might be able to look for clues concerning sentiment from media coverage obtained, sending warnings concerning negative stories as they arise so that PR professionals can respond more quickly. 
While Valin (2018) notes that although the ability of humans to think critically "will be the least affected by AI", other skills - such as those which should be done through basic research, content development, programme evaluation, problem tracking, and many work processes - have already shown a number of AI. One common theme in popular literature is the assumption that AI cannot replace human creativity (Valin, 2018). However, Amos (2016) challenges the idea that creativity is a unique human endeavour that cannot be deconstructed and replicated by machines. He argues that this is untrue. Computational creativity as one of AI's most vigorous fields of research and algorithms have been developed to make music, write poetry, and develop new formulas independently (Amos, 2016). Given the newly released IBM technology - titled Project Debater - which allows machines to debate humans (Kelleher, 2018), it makes sense to suggest that AI can support public relations managers in their role as organisational advisers. This artificial intelligence collaborates with big data technology systematically. By using this artificial intelligence, companies will not only leave the old working patterns of public relations which are still manual but also use the artificial intelligence device as a tool to measure the performance of public relations (Dewi, 2019).

Content automation is better known in the journalism industry. The algorithm is used to generate news automatically from structured data. The Algorithm process carries out content automation through five steps. The first step, the available data is collected through software. Second, statistical methods are used by algorithms to identify important events. Third, classification and priority are determined by software based on interests. Fourth, appropriate elements are arranged as narratives. Finally, stories can be uploaded to the publisher's content management system, which can be published automatically. The content automation can be seen in Figure 1 below:

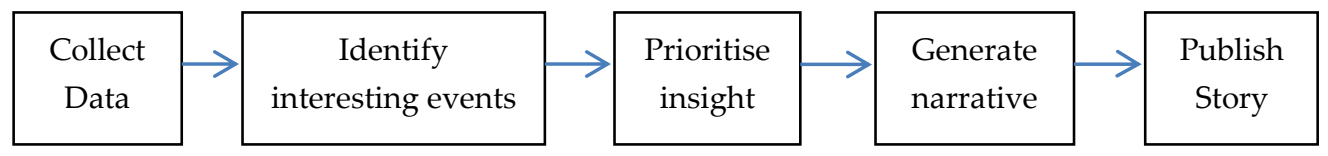

Figure 1: Process Algorithms for Content Automation (Source: Graefe [2016].)

Based on a number of studies conducted above, it is shown that the role of AI in public relations is in an important position in the current era of the Industrial Revolution 4.0. Nevertheless, the role of Human Resources-HR is still important in the communications industry. The USC Annenberg Center For Public Relations (2019) show that 47 percent of respondents who are professional PR estimate that in the next five years $H R$ is still more important than 
technology. However, 46 percent of student respondents rate otherwise. Meanwhile, 30 percent of PR professionals and 24 percent of students consider that both HR and technology are two things that are equally important in the world of communications industry (USC Annenberg Center For Public Relations, 2019). Companies should not be afraid of big data and AI. They should embrace trends and experiment with new stories to fit the analysis and message of big data of the audience. Artificial intelligence is a beneficial tool for public relations practitioners and not just a threat. Using artificial intelligence in the public relations industry will provide faster and optimal results and allow practitioners to achieve their goals faster (Rogers, 2019).

The function of government public relations (GPR) becomes a 'link' or 'bridge' between the institution and the public, so that a good image of the institution will constantly be retained. These activities are the main tasks and functions of public relations. According to public relations expert, James E. Grunig, the definition of public relations is as a management of communication between organisations and the interacting public. Meanwhile, according to Grunig and Hunt (1984), there are four models used in public relations activities, namely Press Agentry, Public Information, Two-Way Communication Asymmetrical, and Two-Way Communication Asymmetrical. The Press Agentry model is strongly influenced by the role of press agents who work to influence public opinion by creating news. Sometimes the aim is to manipulate and emphasise public relations practices which focus on the promotion, publicity, and public propaganda efforts (Lattimore, Baskin, Heiman, \& Toth, 2010), while Public Information model is still dominant in distributing information. Nevertheless, the model is different from the first model since it is not used to manipulate the public and emphasises more on providing honest information (Butterick, 2012). Meanwhile, the Two-way Communication Asymmetrical model emphasises the persuasion which can trigger transactions until popularity emerge. The model is still trying to position the public as a party that must change according to the wishes of the institution and not vice versa (Lattimore et al., 2010).

While the Two-way Communication Symmetrical Model emphasises on the willingness of both parties to adjust to each other, Grunig and Hunt then claim this model as the best model, which can determine the success of public relations practices in institutions (Butterick, 2012). In accordance with the research conducted by J. E. Grunig and L. A. Grunig (1992) regarding the estimation of the application of four PR models in an organisation, it is known that the most widely used model in organisations is the public information model. Other PR models that are widely used sequentially are press agent, two- 
way asymmetric, and two-way symmetric. The most widely used public information model in carrying out PR activities utilise the media as a liaison between the organisation and its public (Grunig \& Grunig, 1992).

The internal and external communication implementation is supposed to filter (to screen), manage and present the information needed so as to be in accordance with the communication needs of the intended target group. Managing and filtering external input provide healthy communication with the community, thereby support and approve as expected (Widjaja, 1997).

Thus a good and amicable communication between public relations in Government Agencies and the public or community will be established. Moreover, the public will be knowledgeable about the activities within the government regarding the policies that have and will be implemented by the Government. In increasing the level of participation/engagement from the community, it can improve the quality of decisions made. By using technology, applications can be made to build citizen participation. Citizen participation is also important as it serves to strengthen legitimacy

\section{Prior Research}

A number of previous studies have been studied by researchers as a comparison and to understand the position of the study and the values of novelty in this study, including the followings:

\section{New Public Relations (PR) Competencies in the Era of Artificial Intelligence: Case Study of PR Practitioners in Indonesia}

In this research, it is known that some PR jobs can be replaced by big data and AI technology, among others: news clippings as much as $45 \%$; news analysis in the media by $45 \%$; media and stakeholder relations by $37 \%$; social media content management by 34\%; distributing releases by 33\%; $24 \%$ photos and videos; jobs that are less likely to be replaced by machines are presentations or face to face communication (18\%). The conclusion obtained in this study is that humans are still needed at a more strategic level of public relations activities, such as analysing further data from media monitoring results, which are predictive and preventive or prescriptive. Research also produces new public relations competencies, among others: competencies for data analysis, social media management, influencers and content creators (Arief \& Saputra, 2019).

\section{Anticipating the Post Human Era in Public Relations}

This research explains the ever improving Industry 4.0, so of course, it will have an impact on the role of PR. The change in role is forcing a shift in the definition 
of community relations itself. The advent of Technology 4.0 not only brings several opportunities into the field of public relations but also challenges. Public relations has a duty to maintain the company's image and reputation. The ability to use new technological tools is very important in the post-human era (Binsar \& Salamah, 2018).

\section{The Challenges of the New Digital Communication and the Industrial Revolution 4.0}

This research discusses the new digital communication, and also how Industry 4.0 has changed the way Public Relations practitioners work, relate and communicate with the public. The new digital and industrial communication 4.0 is a challenge for practitioners to improve their technical and managerial skills as professionals. The term Industry 4.0 was born from the idea of a fourth Industrial Revolution. Its existence offers many potential benefits. In order to realise Industry 4.0, the involvement of academics in the form of research is needed (Dalimunte, Paramita, \& Adilla, 2018).

Digital Public Relations Study: Transformation and Contribution of Industry 4.0 in Public Relations Strategic

This study aims to discuss public relations strategies which are increasingly complex after transforming as it enters the industrial era 4.0. The results found in this study are that the public relations industry has adopted a number of strategies prioritising funding efficiency, high mobilisation and achievement targets. So it can be concluded that the current public relations strategy reflects a pattern which emerge due to the disruption of industry 4.0 (Meranti \& Irwansyah, 2018).

\section{Corporate Communication in the Industrial Era 4.0}

This study aims to determine the conceptual understanding of corporate communication in the Industrial era 4.0. The conclusion obtained from this research is that strategic and adaptive corporate communication is very important, given that the exchange of information between corporations, the public and the environment will create organisational harmony, so plans and activities can be coordinated and environmental uncertainty can be reduced. Media identification and appropriate public analysis will have an impact on effective and targeted corporate communication (Purwadini \& Irwansyah, 2018). 


\section{Effectiveness of Digital Public Relations Tools on Various Customer Segments}

This study aims to measure the effectiveness of digital public relations in various customer segments. Digital public relations is an important component of digital marketing and has an increasingly important position in the e-commerce market (Gulerman, 2017).

\section{The Development of Marketing Communications under the Influence of the Industry 4.0}

This research reviews the development of marketing communication influenced by Industry 4.0. Special attention in this research is given to studies on the relationship between virtual and real economic space when modern companies spread marketing activities (Shkurupskaya \& Litovchenko, 2016).

\section{A Review of the Impact of New Media on Public Relations: Challenges for} Terrain, Practice and Education

This research brings together the main findings from the latest literature to improve overall understanding linked with current and future related challenges posed by new media for public relations (James, 2008).

Previous research above discusses the relationship between Public Relations-PR with advanced technology and also new media. Meanwhile, this research tends to discuss and predict the readiness of the Government Public Relations-GPR in the era of the Industrial Revolution 4.0 in Indonesia with the Focus Group Discussions-FGD method. Thus, research on GPR in Industrial 4.0 era in Indonesia is an investigation which has never been previously performed.

\section{Methodology}

A qualitative approach was used in this study. The paradigm used in this study is the Constructivist paradigm. Through the Constructivist paradigm, researchers can construct the concept of GPR development in the era of the Industrial Revolution 4.0 based on the knowledge, understanding, and experience of social actors and experts and the analysis of the researchers themselves.

Data collection was carried out five times by Focus Group DiscussionsFGD. Each FGD implementation has objectives which include:

\section{The 1st FGD}

The 1st FGD was held on July 16, 2019 with the speaker from Ministry for Communication and Informatics Selamatta Sembiring and Dedy Hermawan, and 
academicians in the field of GPR and in Information Technology. This FGD aims to identify the existing conditions of GPR Kominfo and the development of GPR in the era of the Industrial Revolution 4.0.

\section{The second FGD}

The second FGD was held on July 23, 2019 with NTMC Polri AKBP resource person, Dhapi and Wahyutama's public communication academics. This FGD aimed to identify the use of advanced technology in public services in Indonesia and public engagement in a symmetrical, balanced GPR communication system.

\section{The 3rd FGD}

The 3rd FGD was held on July 30, 2019 by presenting the Editor in Chief of Beritagar.id, Yusro M. Santoso, Director of the Telecommunication ProfessionalCertification Body Bambang Priantono, and PR practitioners from KayuApi Digital Reputation Arya Gumilar Founders as spokespersons. This FGD aims to identify content automation in the world of journalism and public relations and the GPR communication system in the era of the Industrial Revolution 4.0.

\section{The 4th FGD}

The 4th FGD was held on October 5, 2019 with the guest speakers, Dyah Rachmawati (IPRA Humas), Ajeng Liestyorini (Ministry of PAN RB), and Nuruning (Jakarta ICT Department of Communication and Information Technology). The 4th FGD was held to identify the development of the concept of GPR in the era of the Industrial Revolution 4.0 on the HR aspect.

\section{The 5th FGD}

The 5th FGD was held on October 16, 2019, by the Head of the Ministry of Communication and Informatics Human Resources Development Agency with the resource persons Basuki Yusuf Iskandar, Director General of IKP Widodo Muktiyo, Public Communications Specialist Gun-Gun Heriyanto, Association of Public Relations-Perhumas Heri Rakhmadi. The focus group discussion was aimed at assessing experts on the results of data collection, analysis, and tentative conclusions presented by the research team.

The FGD method based on practicality and cost is a costeffective/inexpensive, flexible, practical, elaborative data collection method and can collect more data from respondents in a short time (Streubert \& Carpenter, 2003). In addition, the FGD method facilitates the freedom of expression of the individuals involved and allows researchers to increase the number of their research samples. In terms of validity, the FGD method is a method that has a 
high level of face validity and is generally oriented towards research procedures (Lehoux, Poland, \& Daudelin, 2006). Data analysis was performed using the M. B. Miles and A. M. Huberman (1984) model. The categorisation of the FGD data results was carried out to describe the existing conditions and expected conditions of the GPR of the Minister of Communication and Informatics. And then, a matrix frame is carried out to identify the GPR communication strategy in the Industrial Revolution 4.0 era. Triangulation is done to conclude.

\section{Analysis}

This section identifies the existing conditions from the GPR in the Industrial Revolution 4.0 era, in a case study at the Ministry of Communication and Informatics. Thus, an effective and efficient GPR communication strategy in the Industrial Revolution era 4.0 can be obtained.

\section{Existing Condition}

As the frontline in conveying the latest information about government, Government Public Relations actors must find the right formula to communicate. The government's communication strategy is one of the keys to success in delivering information from the government to the public. However, with the speed of technological development existing in the 4.0 Industry era, the communication strategy used must be updated and adjusted to the existing needs. The GPR communication strategy undertaken by the Ministry of Communication and Information through the Directorate General of Public Communication Information consists of four strategies. The first strategy is Events, which is to synergise activities between the Ministry / Institution / Region - M/I/R to educate and literate, increase news exposure, e.g.: seminars, public discussions, and public lectures. The second strategy is Social Media, namely by strengthening social media with publications utilising cyber army in the $M / I / R$, endorsers, and a single narrative. The third strategy is Communication Strategy, which is the integration of communication strategies between Ministries/Institutions-M/I to compose a single narrative and grand narrative. The fourth strategy is Media Relations, which is merging, coordinating, communicating, and synchronising media relations activities to optimise media exposure. This was done through the activities of the West Merdeka 9 Forum, Joint Press Conference, and Opinion Writing by analysts, and talk shows on television media. According to the Director of Governance and Public Communication Partnership Selamatta Sembiring, the GPR task of the Ministry of Communication and Information is in accordance with Presidential Instruction No. 9 of 2015 concerning Management of Public Communication. As 
he said, "The tasks of the GPR include Program Socialisation, Literacy and education to the public, government priority program campaigns, counter narratives, and national branding" (FGD, July 16, 2019).

While the GPR workflow shows that the Ministry of Communication and Informatics is cooperating with the $\mathrm{M} / \mathrm{I} / \mathrm{R}$ and the Office of the President Staff in carrying out the tasks of the GPR. In the dissemination of information on public policy, the Ministry of Communication and Informatics uses all available communication channels, whether radio, TV, print media, online media, books, media discussion forums, FGDs, seminars and workshops, public shows, panel discussions, blogger festivals, and media social and installation of GPR widgets in 196 local governments and $47 \mathrm{M} / \mathrm{I}$. For social media, the M/I/R social media task force has been formed. According to Selamatta Sembiring, there are currently 97 social media task forces in the $\mathrm{M} / \mathrm{I}$ and 598 social media task forces in the local government (FGD, July 16, 2019).

The number of channels mentioned above also raises some notes and concerns, e.g., the evaluations of these channels are needed to see the effectiveness of precious information delivery. One of them is whether the presence of many channels can reach the aspirations of a millennial generation more effectively, the extent of community engagement and how the community responds to existing government programmes as it is important to develop a GPR framework (FGD, July 16, 2019). The issuance of Presidential Instruction No. 9 of 2015 also became an important milestone in the era of Jokowi-Jusuf Kalla's administration, which is related to the duties and functions of coordinating government public relations. Through this Presidential Instruction, the Directorate General of Public Communication Information is expected to carry out the responsibilities and tasks of coordinating public relations in various ministries and government agencies so that the delivery of information to the public is expected to be carried out quickly, accurately, and of good quality. In addition, it is expected that the formulation of a single narrative as agendasetting is able to provide consistent and balanced government information in society. During this period, 45 people were recruited to support the communication management of government institutions through the Professional Public Relations programme. On the other hand, something worthy to note is that the absence of an audience map is also a stumbling block to map the provision of information in accordance with the needs of the community. Therefore, the Directorate General of Public Communication Information is expected to be able to make an audience distribution map to be used as a reference for GPR in sharing information (FGD, July 16, 2019). Another note needs to be considered in FGDs related to a single narrative is that this provides 
its own challenges related to communication in the current era because it tends to be slow and unresponsive, namely how to make the single vision and be able to become the policy of each agency (FGD, 23 July 2019).

Related to the implemented communication strategy by GPR at the existing conditions, there are still a lot who do the work system approach manually, as stated by Dedy Hermawan, Special Staff of the Minister of Communication and Information Technology (FGD, July 16, 2019). The use of digital technology becomes important, especially in relation to the transformation of government public relations facilitated by technology. Technology is placed as an owned instrument or tool, especially in improving the ability of institutions to serve citizens, and increase citizens sense of security by providing an integrated monitoring system between technology and communication. Technology is only an enabler, so in taking the capacity to change, it should not give up full control over technology. Still, better technology should be linked to developing the capabilities we have, namely a more effective government in serving citizens' rights as conveyed by academician, Wahyutama (FGD, 23 July 2019). Deddy Hermawan, special staff of the Minister of Communication and Informatics, said the weakness of the GPR is the absence of synergy among the M/I/R. The communication channels used by the GPR of the Ministry of Communication and Informatics are too excessive in the dissemination of information. He was apprehensive that too many channels could cause less focus in the dissemination of information in connection with public policy. When in discussion concerning GPR in the era of the Industrial Revolution 4.0, Deddy Hermawan reveals that content automation, Robotic and AI are not in use by the GPR of Ministry of Communication and Informatics. Based on his observations, no government uses these tools yet, "From the aspect of production, no one has used the advanced technology yet. But in the community already produces digital hoaxes. Therefore, in the future, it is necessary to prepare a GPR using advanced technology" (FGD, July 16, 2019).

Meanwhile, according to an academician from the University of Paramadina Jakarta, Ika K Idris, the current GPR practice has the same message content but with a different package. Government-owned social media accounts tend to disseminate positive information concerning the government. Meanwhile, public participation in social media is important in this digital age, but the interaction of netizens in social media does not yet reflect public participation.

Dialogue has never been part of government PR activities in Indonesia, even in the possible communication channel: social media. Social media 
usage counts (followers, likes, shares, comments) are not viable measures of public participation. GPR focuses on disseminating and amplifying messages on social media. (FGD, July 16, 2019)

\section{The Expected Conditions}

GPR 4.0 is an expected GPR condition in the future. Therefore, the definition of GPR 4.0 in this study is as follows:

As a form of government communication management between government organisations and the public, both from internal organisations and from external organisations using advanced technology (robots, drones, \& artificial intelligence), which is supported by high speed internet and big data analytics. (FGD, July 16, 2019)

Based on these definitions, the second and third FGDs invited the NTMC leaders of the Indonesian National Police and the chief editor of the Beritagar Editor. Both have implemented advanced technology in public relations activities. The NTMC uses AI in collaboration with Google to inform the public regarding traffic accident cases. In addition, it uses 2069 CCTV and drones as well as big data for traffic monitoring. As they said, "We use call centre facilities, social media integrated in www.ntmckorlantas, and text messaging ... Then there is also an application, which can monitor motor vehicle data ... we also cooperate with google regarding traffic accident information" (FGD, July 23, 2019).

Meanwhile, Beritagar.id is the first news site in Indonesia to utilise advanced technology in gathering and analysing various contents for reporting using AI. According to the informants, "The engine we created to create content automatically. The same thing can be built to help the GPR team of the Ministry of Communication and Informatics in formulating content, after formulating content, how it is disseminated" (FGD, 30 July 2019).

While the Director of the Professional Certification Institute Bambang Priantono said, in GPR 4.0, the government must make priorities and deliver the correct news in the dissemination of information, "At the moment, the government must prioritise. The community needs something as a verifier to hold onto.... If it is the government, it should be the first to deliver the correct news." (FGD, 30 July 2019).

Meanwhile, PR practitioner, Jojo S. Nugroho, said that storytelling combined with technology would become a trend in the future, "When public relations executives were asked which communications trends will be the most 
important in the next 5 years, digital storytelling ranked above the rest, followed by social listening, social purpose and big data" (FGD, July 16, 2019).

Therefore, in the future, besides having skills in the field of PR, GPR Human Resources also have skills related to advanced technology such as Machine Learning (ML) based technology and Natural Language Processing (NLP). As the informants said, "In technology, there should be a programmer who is good at making machine learning, then big data. The editor must also understand how to be able to make machine learning, Natural Language Processing-NLP or Natural language generation-NLG" (FGD, 30 July 2019).

\section{Findings and Discussions}

Based on the results of the FGD above, a comparison is made between the existing conditions and the expected conditions from GPR in the Industrial Revolution 4.0 era at the Ministry of Communication and Informatics in the Republic of Indonesia as constructed in Table 1.

Table 1: Comparison of Existing and Expected Conditions of GPR in the Industrial Revolution 4.0 Era

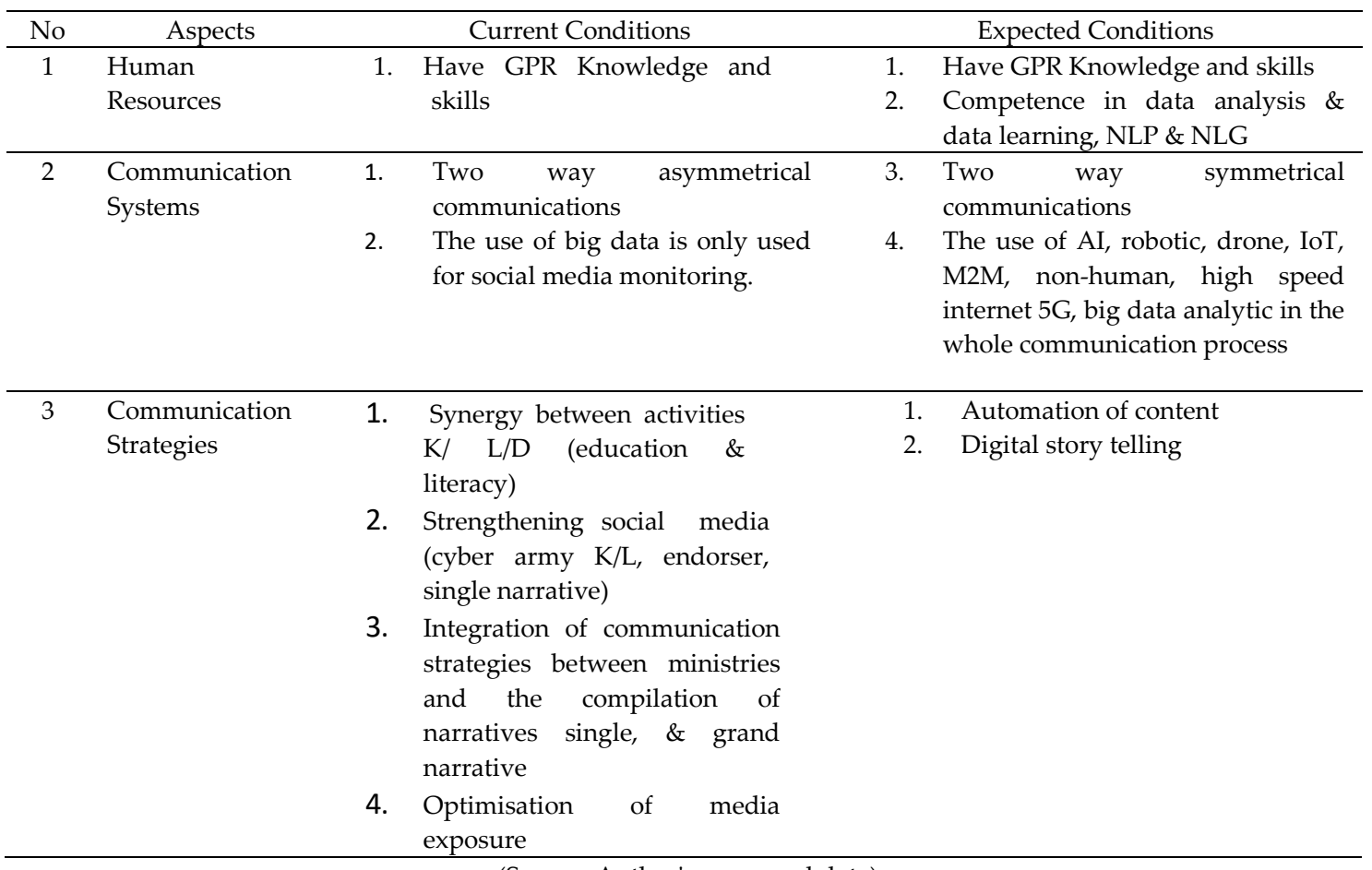

(Source: Author's processed data) 
Based on the results above, it is found that there are two communication strategies which can be used by the GPR of Ministry of Communication and Informatics in the Industrial Revolution 4.0 era, namely content automation and digital storytelling.

Content automation is an alternative in the implementation of GPR at the Ministry of Communication and Informatics, especially in anticipating various negative content such as hoaxes and hate speeches which circulate a lot on the internet related to Indonesian government policies. Daily briefs in the form of a single narrative can be created through content automation. Content automation is specifically carried out on data which does not require re-verification, such as regarding government regulations and policies that have been established and data from the Central Statistics Agency. Nevertheless, the role of professional public relations personnel with competence in the field of public relations and advanced technology is still needed. So, content production is pure content automation (non-human), and collaboration between machines and humans are available.

While the second communication strategy is digital storytelling, delivering messages with storytelling combined with digital technology is an effective way in the industrial era 4.0. Digital storytelling packaged with videos or pictures is the main attraction for netizens. Information dissemination through digital storytelling can be done faster as some people tend to use social media and messenger applications to obtain the latest information. This communication strategy can be said to be useful since it increases the attachment between the message maker and the recipient of the message, which will then become the next message maker. By reproducing messages differently, the understanding of the contents of the information previously delivered by the government is deeper. Likewise, the recipient of the next message will notice the information he got was not directly from the government, and this could increase trust in the contents of the information.

The two communication strategies above can be carried out with the support of human resources and communication systems with the use of advanced technology. GPR Human Resources in the era of the Industrial Revolution 4.0 are also expected to have data analysis and data learning competencies. The ability of public relations equipped with skills in advanced technology such as AI can support the implementation of communication strategies. Thus, two-way symmetrical communications can be created between the government and the public through the use of advanced technology. 


\section{Conclusion and Recommendations}

The existence of advanced technologies such as AI and big data has an impact on the GPR communication strategy in the era of the Industrial Revolution 4.0. The use of AI and big data in content automation is needed by the GPR of Ministry of Communication and Informatics to be responsive to various existing negative content. Although every information can be implemented by content automation, different government policy information which requires the depth of a story and having data that needs to be verified indeed still requires the existence of GPR Human Resources.

The second strategy is digital storytelling which can be accomplished by a collaboration between GPR Human Resources and advanced technology. The role of GPR Human Resources is still important since not every information can be created through content automation. Even though, AI has now been developed for artworks such as music and paintings, the ability of GPR Human Resources such as telling stories and being a good listener may not be irreplaceable. To realise these two communication strategies, GPR Human Resources are required to have capabilities in advanced technology fields such as Natural Language Processing (NLP) \& Natural language generation (NLG).

In-depth study in connection with the relationship between AI and big data in the world of public relations is still important in the future. The potential use of AI and big data is expected to facilitate the performance of professional PR and GPR in response to various information challenges in the era of the Industrial Revolution 4.0 which is full of information uncertainty.

\section{Acknowledgements}

This research was funded by the Human Resources Research and Development Agency of the Ministry of Communication and Information of the Republic of Indonesia with the support of the 2019 State Budget on SP DIPA-059.06-0/2019. I would like to convey my gratitude to the Head of the HR Research and Development Agency Dr. Ir. Basuki Yusuf Iskandar MA, who has encouraged the realisation of this research. Likewise, thank you to my colleagues at the HR Research and Development Agency who supported and provided input for the completion of this study.

\section{References}

Agolla, J. E. (2018). Human Capital in the Smart Manufacturing and Industry 4.0 Revolution. Digital Transformation in Smart Manufacturing. Retrieved from https://doi.org/10.5772/intechopen.73575 
Amos, D. (2016). What Does Artificial Intelligence Mean for Public Relations? The Power of Communication (PRCA). Retrieved from https://www.prca.org.uk/AIinPR

APJII. (2019). Penetrasi \& Profil Perilaku Pengguna Internet Indonesia Tahun 2018. Apjii, 51. Retrieved from www.apjii.or.id

Arief, N. N., \& Saputra, M. A. A. (2019). Kompetensi Baru Public Relations (PR) Pada Era Artificial Intelligence. Jurnal Sistem Cerdas, 2(1), 1-12. Retrieved from https://doi.org/10.37396/jsc.v2i1.19

Binsar, A., \& Salamah, U. (2018). Anticipating the Post Human Era in Public Relations. In 2nd Indonesia International Graduate Conference on Communication (Indo-IGCC) Proceeding (pp. 373-392). Depok: Universitas Indonesia.

Butterick, K. (2012). Pengantar Public Relations: Teori dan Praktik. Jakarta: RajaGrafindo Persada.

Dalimunte, R. P., Paramita, H., \& Adilla, S. (2018). Tantangan Komunikasi Baru Digital dan Revolusi Industri 4.0. Prosiding Konferensi Nasional Komunikasi, 2(1), 789-794. Retrieved from http://www.pknk.org/index.php/PKNK/article/view/212/202

Deny, S. (2018). Dihadiri Jokowi, Indonesia 4.0 Resmi Diluncurkan Hadapi Revolusi Industri ke-4. Retrieved from https://www.merdeka.com/uang/dihadiri-jokowi-indonesia-40-resmidiluncurkan-hadapi-revolusi-industri-ke-4.html

Dewi, E. N. (2019). Profesi Public Relations Akan Tergerus Artificial Intelligence. Retrieved from https://www.pikiran-rakyat.com/bandungraya/2019/02/17/profesi-public-relations-akan-tergerus-artificialintelligence

Dolphin, R. R. (2004). Corporate Reputation - A Value Creating Strategy. Corporate Governance International Journal of Business in Society, 4(3), 7792.

Graefe, A. (2016). Guide to Automated Journalism. Columbia Journalism Review. Retrieved from https://www.cjr.org/tow_center_reports/guide_to_automated journalism.php

Grunig, J. E., \& Grunig, L. A. (1992). Models of Public Relations and Communication. In J. E Grunig (Ed.), Excellence in Public Relations and Communication Management (pp. 285-325). Hillsdale: Lawrence Erlbaum.

Grunig, J., \& Hunt, T. (1984). Managing Public Relations. New York: Holt, Rinehart and Winston.

Gulerman, N. I., \& Apaydın, F. (2017). Effectiveness of Digital Public Relations 
Tools on Different Customer Segments. 2nd World Conference on Technology, Innovation and Entrepreneurship, 4, 37-48. https://doi.org/10.17261/Pressacademia.2017

James, M. (2008). A Review of the Impact of New Media On Public Relations: Challenges for Terrain, Practice and Education. Asia Pacific Public Relations Journal, 8, 137-148.

Kelleher, K. (2018). This AI Has Been Debating Real Humans - And Doing A Pretty Good Job. Retrieved from https://www.weforum.org/agenda/2018/06/ibms-jeopardy-winning-aiis-now-ready-to-debate-you

Laksamana, A. (2018). Humas Indonesia Menuju Industri 4.0. Retrieved from https://www.wartaekonomi.co.id/read182081/humas-indonesiamenuju-industri-40.html

Lattimore, D., Baskin, O., Heiman, S. T., \& Toth, E. L. (2010). Public Relations: Profesi dan Praktik. Salemba: Humanika.

Lehoux, P., Poland, B., \& Daudelin, G. (2006). Focus Group Research and "the Patient's View". Social Science and Medicine, 63(8), 2091-2104. Retrieved from https://doi.org/10.1016/j.socscimed.2006.05.016

Lye, D. (2017). The Fourth Industrial Revolution and Challenges For Government. Retrieved from https://www.brinknews.com/the-fourthindustrial-revolution-and-challenges-for-government/

Lynch, C. (2018). How PR Pros Should Prepare for Artificial Intelligence. Retrieved from https://www.prdaily.com/Main/Articles/482543a6-4e1f4111-af8b-9e46019028cc.aspx.

Mastel. (2017). Hasil Survey Mastel Tentang Wabah Hoax Nasional. Mastel, 18. Retrieved from http://mastel.id/press-release-infografis-hasil-surveymastel-tentang-wabah-hoax-nasional/

Meranti, \& Irwansyah. (2018). Kajian Humas Digital: Transformasi dan Kontribusi Industri 4.0 pada Stratejik Kehumasan. Jurnal Teknologi Informasi Dan Komunikasi, 7(1), 27-36.

Miles, M. B., \& Huberman, A. M. (1984). Drawing Valid Meaning from Qualitative Data: Toward a Shared Craft. Educational Researcher, 13(5), 20-30. Retrieved from https://doi.org/10.3102/0013189X013005020

Ministry of Industry. (2018). Making Indonesia 4.0 Bikin Industri Nasional Berdaya Saing Global di Era Digital. Retrieved from https://kemenperin.go.id/artikel/19046/Making-Indonesia-4.0-BikinIndustri-Nasional-Berdaya-Saing-Global-di-Era-Digital

Purwadini, D. A., \& Irwansyah, I. (2018). Komunikasi Korporasi Pada Era Industri 4.0. Jurnal Ilmu Sosial, 17(1), 53. Retrieved from 
https://doi.org/10.14710/jis.17.1.2018.53-63

Ristic, D. (2017). PR in 2018: Dominated by Technology, Mired by Inauthenticity. Retrieved from https://www.prweek.com/article/1453426/pr-2018dominated-technology-mired-inauthenticity

Rogers, C. (2019). How Artificial Intelligence and Big Data will Affect the Future of PR. Retrieved from https://instituteforpr.org/how-artificialintelligence-and-big-data-will-affect-the-future-of-pr/

Savitri, A. (2019). Revolusi Industri 4.0: Mengubah Tantangan Menjadi Peluang di Era Disrupsi 4.0. Yogyakarta: Genesis.

Scott, A. (2018, June 6). How Artificial Intelligence and Intergenerational Diversity are Creating Anxiety in the Workplace. Institute for Public Relations. Retrieved from https://instituteforpr.org/how-artificial-intelligence-andintergenerational-diversity-is-creating-anxiety-in-the-workplace/

Shkurupskaya, \& Litovchenko. (2016). The Development of Marketing Communications under the Influence of the Industry 4.0. International Scientific Conference "Industry 4.0", 2(XXIV), 19-22.

Skinner, C. (2018). Manusia Digital: Revolusi 4.0 Melibatkan Semua Orang. Jakarta: Elek Media Komputindo.

Streubert, H. J., \& Carpenter, D. R. (2003). Qualitative Research in Nursing: Advancing the Humanistic Imperative. New York: Lippincott William \& Wilkins.

Sukmana, Y. (2019, April 15). Pemerintah Luncurkan INDI 4.0, Apa Itu? Retrieved from

https://money.kompas.com/read/2019/04/15/120758026/pemerintahluncurkan-indi-40-apa-itu

USC Annenberg Center For Public Relations. (2019). 2019 Global Communications Report: PR:TECH, The Future of Technology in Communication. Retrieved from http://assets.uscannenberg.org/docs/2019-global-communicationsreport.pdf

Valin, J. (2018). Humans Still Needed: An Analysis of Skills and Tools in Public Relation (Discussion paper). London: CIPR. Retrieved from https://www.cipr.co.uk/sites/default/files/11497_CIPR_AIinPR_A4_v7. pdf.

Widjaja, H. A. W. (1997). Komunikasi dan Hubungan Masyarakat. Jakarta: Bumi Aksara.

Date Received: 21 January 2020 Date of Acceptance: 1 June 2020 